\title{
Still Going after all these Years: Text, Truth and the Racing Calendar
}

When The Turf was published in 1976, Wray Vamplew could not have imagined that his contribution to the economic and social history of horseracing had only just begun and was to span the next thirty years. [1] None of his subsequent books, articles or conference papers on racing topics as diverse as the impact of the Victorian railways, the demise of the Edwardian gentleman rider, the bizarre and often dangerous life of the twentiethcentury professional jockey or the rise and fall of the Jockey Club could have been written - let alone quantified - without recourse to 'the official organ of the racing authorities', the Racing Calendar. [2] This paper will briefly outline its history, analyse its contents and attempt to evaluate its worth as a comprehensive and reliable source. It will then seek to illustrate some ways in which historians of racing can still use this extraordinary sporting series.

\section{Time after time}

'Horseracing is one of the oldest sports in the world' and the Racing Calendar is a time-honoured chronicle of its evolution in Britain. [3] Although it has been claimed that 'no other branch of sport can boast of records dating back in this unbroken manner for two centuries', [4] this refers only to Weatherbys' volumes. It is now nearly three hundred years since John Cheny published his original 'Account of all the Horse-Matches Run and of all the Plates and Prizes run for in England (of the Value of Ten Pounds or upwards)' in 1727. The scope of this Calendar-advertised as including the owners, the names and colours of the horses, the winners and places, and the 'conditions of running as to weight, age, size etc.', together with a list of the principal cock fights - had entailed considerable travelling around the country as Cheny built up a network of acquaintance who thereafter supplied him with reports of local meetings and matches. In this way he obtained 'a fairly complete return' but the limitations of the work are obvious, with races restricted not only by his personal information gathering but also, as the title-page suggests, by value and geography. ('England' was later to become Great Britain and Ireland.) From 1732 he employed two or three servants to ride out collecting intelligence during the flat racing season and was therefore able to supplement the annual with a fortnightly 'sheet calendar' from mid-April to the end of October containing details of racing for the previous two weeks. For these services he charged subscribers half a guinea. [5]

Cheny continued to publish his Calendar yearly until his death in 1751 . By then the contents had been expanded to include the pedigrees of principal runners, a list and description of the 'places of sport' and a rudimentary index of horses. The following two decades saw various entrepreneurs carry on a similar format but with several significant additions. John Pond's Kalendar (1751-1758) included the first set of general rules of racing and the first mention of the Jockey Club, later to become the regulatory authority of horseracing in Britain. Heber's Calendar (1751-1768) contained the original list of racing colours registered by owners and the earliest reference to racing overseas (Philadelphia). [6] A period of intense rivalry, amounting even to skulduggery and threatened law-suits, followed Heber's death in 1768, during which partnerships 
involving Messrs. Thomas Fawconer, William Tuting and James Weatherby were formed and dissolved. The eventual winner of this publishing contest was Weatherby, now Keeper of the Match Book at Newmarket. His initial format retained some features of earlier Calendars including a list of meetings and of racing colours, an index of horses and the fortnightly production of the sheet calendar. It dispensed with others, notably Pond's general rules of racing, and added a register of subscribers and an expanded set of Jockey Club rules. By the time of Fawconer's death in 1778 Weatherby's Racing Calendar had established itself as the sole heir to Cheny's original work.

It is still going 230 years later, although aesthetically it is a mere shadow of its former self. Until the late 1960s it was bound in hard brown covers with red and black leather title strips on the spine, the lettering and decorative bars in shiny gold - a fat, seductive volume, fit to grace the library of any Georgian aristocrat or line the study walls of any Victorian squire. It had continued to expand in size throughout the twentieth century, reflecting the growth of British horseracing - some editions were over three inches thick. In its final years, however, its appearance metamorphosed to a rather nasty shade of sickly yellow and its contents were radically reduced, focusing almost exclusively on race results and racehorses. It eventually ceased to appear in book form in 1989 but continues to be published weekly for the benefit of the modern multi-million pound racing industry. Over the years it has evolved from a privately printed commercial venture by the Weatherby family, through a lengthy period of semi-autonomy in which it clearly acted as the unofficial mouthpiece of the Jockey Club, to a point in 1902 when it was purchased by racing's governing body. For much of the twentieth century it continued to be 'published for the Jockey Club by Weatherby and Sons', while the expanding firm cemented its position in racing administration - registering owners, horses and racing colours, receiving entries and declarations, allocating weights, issuing official lists of runners and riders, and collecting and distributing prize money. Weatherbys is still responsible for the day-to-day running of British horseracing under contract to the present regulators, the British Horseracing Authority, but the traditional form of the Racing Calendar is no more.

\section{Times they are a-changin'?}

One of the remarkable aspects of the Racing Calendar is how little it changed for

much of its history. A Georgian racehorse owner would still have recognised many of the basic contents of the annual volume two hundred years later, even if the terminology had altered. The index of meetings held, the results of past races, the details of stallions' fees, the lengths of the racecourses and the register of winning horses were still there in 1968 as they had been in 1778. Gone were the references to cocking - banned in 1840; future races - printed separately from 1846; King's or Queen's Plates - a type of race abandoned in 1887; subscribers - subscription lists ceased to be published in 1888; and racing colours - ended in 1963 when the details of registered owners' silks had reached 106 pages.

What would probably have surprised him was the sheer amount of official information included. General rules and regulations of horseracing, a wealth of data relating to the Jockey Club and lists of licensed racing personnel such as trainers, 
officials and jockeys had turned the annual Racing Calendar into a substantial and authoritative-looking publication by the twentieth century. Seven pages of rules in 1807 had become 21 in 1852, 56 in 1904 and 88 by 1968 - the index of rules alone ran to 21 pages. A list of Jockey Club members, first introduced in 1835, was later augmented by committee membership, reports of proceedings and over 50 pages of stewards' enquiries. Jockeys, too lowly to even be named in the race results until 1823, had to apply for annual licenses from 1879 and those authorised to ride had their names printed each year. Their numbers peaked at just over 300 in the 1920s, falling back to around 220 in the post-1945 decades, a period at which apprentices reached double that figure and licensed trainers numbered over 250 .

The potential for charting the growth and development of horseracing through the pages of this continuous series would therefore seem to be considerable and economic and social historians of the sport such as Wray Vamplew, Mike Huggins and John Tolson have used it extensively. It is possible to analyse the changing geography, extent and gradual concentration of racing in certain parts of the country as some traditional courses and meetings faded into obscurity or oblivion while others took their place. Numbers of race meetings, when they were held and for how many days, lengths of jockey or racehorse careers and their success rates, changing patterns of racing such as the demise of heats and yearling races or the proportion of two-year-old racers, can all be discovered. An economic historian can calculate the amount and growth of prize money within the sport over a period of time; a social historian can find out who won it and who donated the many racing trophies to successful owners. It is a racing anorak's paradise but...

\section{There's just one problem}

Historians of horseracing have not needed a deconstructionist to alert them to possible flaws in the Racing Calendar as a source. Over thirty years ago, Wray Vamplew recognised that the race meetings contained in its nineteenth-century volumes did not amount to a comprehensive register of racing in Britain and that there was, additionally, a 'fluctuating set of lesser events, extremely local in character and seldom having a permanent date in the Racing Calendar'. [7] Mike Huggins cast an even more critical eye over its contents and possible defects as a barometer of horseracing, pointing out, for example, that the annual list of racing colours contained so many lifetime registrations that it was an imperfect gauge of upper-class, titled participation: it did not guarantee that owners were active in any particular year. [8] The most problematic issue with Weatherbys' tomes, however, is that they might easily be characterised as 'sites of power', in the terminology of Doug Booth. Before they can be approved as historical sources, we have to consider who they were written for, why they were written, who might benefit from their publication and what material was included or omitted. [9]

When Cheny first published his Calendar, he suggested that 'in the midst of Winter, [it] will be an agreeable Amusement, in that dull, inactive season, rendering Gentlemen capable, even in their Chambers, of diverting themselves with a Prospect, as it were, of the Sport of each past year...' [10] His was a commercial, money-making enterprise that aimed to supply information to racegoers, owners and bettors throughout 
the country. When James Weatherby began to compile his own work in 1773 he undertook the same task but with an important difference: he had been an official at Newmarket, already the headquarters of horseracing, for some years. Undoubtedly Keeper of the Match Book - a title printed on the frontispiece of his Racing Calendars he may also have been known as Secretary to the Jockey Club by this time, a designation previously used by his erstwhile publishing partner, Thomas Fawconer. Several sources are of the opinion that a member of the Weatherby family held this post continuously for two hundred years from the early 1770s; Wray Vamplew himself considered James Weatherby to be Keeper of the Match Book and Club Secretary from 1771. [11]

In his second volume, Mr Weatherby thought fit to trade on his official position, advising prospective clients that this gave him singular advantages over any rival publisher. Furthermore, he continued the item introduced by Messrs Tuting and Fawconer in their 1770 Calendar under the heading 'Orders settled by the Jockey Club'. This became 'Rules and Orders of the Jockey Club' from 1773 and although some were merely regulations applying to the members of that organisation, such as annual dinners or appointments of stewards, others suggest an embryonic code to cover races at Newmarket. [12] Even at this stage the Racing Calendar was a means of disseminating information about the body that was to become the sole arbiter of the sport in Britain; subscribers throughout the country were made aware not only of Club affairs but of the opinions and strictures of elite racing men. Cognisance, however, is a long way from control. Although the Jockey Club was occasionally asked to adjudicate on race disputes outwith Newmarket, it was a further hundred years before it sought to extend its authority over the conduct of racing beyond its home base. [13] Weatherbys' early Racing Calendars are therefore unlikely to be any more biased than those of Cheny and other predecessors: their limitations are largely those of geography and awareness. From 1797 till 1858 they even included Pond's general rules of racing, something which suggests that the Jockey Club was in no hurry to exert a regulatory influence over the sport.

Mike Huggins, however, has been critical of the Racing Calendar as a historical source from the second half of the nineteenth century onwards as it increasingly became the 'de facto mouthpiece of the Club', publishing 'details of such matters as the Club wished to make known more generally, and not those it wished to keep dark.' [14]. As such it appears to represent the type of 'official' document of which Booth cautions us to beware. [15] From the 1870s it could be said to have provided a partial view of British horseracing, concentrating on the financially and socially superior end of the sport to the exclusion of the small, local - and possibly corrupt - meetings that flourished in areas of the country remote from Newmarket. The Jockey Club ruling of 1870 - that only those events that were advertised as subject to its revised, and now extensive, 'Rules concerning Horse-racing in general', published in the Racing Calendar, would have their programmes and results included therein - led to a 30 percent drop in reported meetings within five years. It would seem, nevertheless, that many of the small country fixtures continued 'pretty much on the old lines ... a law unto themselves,' at which 'the local officials constituted themselves into a self-contained Jockey Club and a Messrs. Weatherby's of their own.' [16] 
The way in which the Racing Calendar was used to validate approved aspects of British horseracing - the 1870 ruling was followed by an even more draconian edict from Newmarket in 1877, banning the advertisement within its covers of any meeting that failed to award prize money of more than $£ 300$ - certainly suggests that it increasingly operated as an official digest as well as a commercial undertaking. A two-tier picture of British racing thus emerged: the regulated, relatively wealthy, often multi-day event of licensed horses, jockeys and trainers that attracted members of polite society, and the little, one-day local meet of doubtful nags, dubious organisation and possible dishonesty that continued to provide entertainment for rural or distant communities. From this time on, the Racing Calendar might be viewed as a less than comprehensive record of race meetings and results, although it could be argued that it had probably omitted some of the least noteworthy race days throughout its history.

However, there is no reason to suppose that its official lists - of owners, trainers, jockeys, apprentices, registered colours, rules - or its record of 'approved' race meetings are in any way flawed. It may increasingly have spread the gospel according to the Jockey Club from the middle of the nineteenth century and its omissions may present a rather distorted picture of racing for the ordinary punter but its statistical evidence probably offers the most comprehensive view of British horseracing over a period of two hundred years.

\section{Against all odds?}

One aspect of racing that has not been considered so far is betting, the raison d'etre of the sport according to Huggins, its lifeblood as described by Vamplew. [17] In Cheny's original Racing Calendar the detailed information about horses and their 'form' was proclaimed as a means of assisting subscribers in 'reducing their Calculations nearer to perfection, and consequently of matching or betting with greater advantage.' [18] His was essentially the first form guide for punters; one historian of the Jockey Club likens it to the Timeform or Raceform publications of today. [19] The 1732 edition noted that the methods of deciding bets are 'frequently attended with Disputes and Contentions, too many of which proceed to expensive Law Suits'; it was therefore Cheny's intention to publish the rules of betting founded 'on the Dictates or Judgment of Newmarket.' Nothing came of this proposal. [20]

Although John Pond's Kalendar contained the first published rules of racing and betting, Weatherby, as already noted, initially dispensed with these. When they were reintroduced in 1797, over one-third related to betting, and a further minimum of twelve were to be found amongst the Rules and Orders of the Jockey Club - that is, only applicable to racing at Newmarket - from 1809 to1857. Yet the Club itself was allegedly 'not interested in betting as such, acting only to ensure that ... debts of honour were settled.' [21] As if to emphasise this statement, the revised general and Club rules of 1858 removed references to betting to an appendix; nearly half of the nineteen regulations listed there had originated with Pond a century earlier. While the majority of these had been published under the 'Rules of horse-racing in general' - for example Rule 4 , 'Confirmed bets cannot be "off" except by mutual consent' or Rule 8, 'The person who 
lays the odds has a right to choose a horse or the field: when a person has chosen a horse, the field is what starts against him' - some had previously been included under the Jockey Club code. Rule 5, relating to matches or private sweepstakes between any two horses being rendered null and void if both subsequently became the property of one person, is a Jockey Club ruling; so is the edict that all bets made on the Derby, Oaks, St Leger and several other major races - these change over time - 'shall be considered "play or pay". Why these were previously part of separate codes is unknown and the significance of that separation is lost on the author! [22]

A further revision of the Rules of Racing in 1889 saw the disappearance of the appendix on betting and the re-instatement of two items (out of 184) on 'Bets, defaulters for'. Rule 18 stated that 'The Stewards of the Jockey Club take no cognisance of any disputes or claims with respect to bets', a re-iteration of the original 'hands-off' stance adopted in 1842 which had freed them from any responsibility for gambling matters, even at Newmarket. [23] Rule 177 noted that defaulters would be 'warned off'. These two remained part of the general rules printed in the Racing Calendar until they ceased to be published in 1970. The removal of the archaic and unnecessary 'Colours worn by the riders' in 1963 made space for the publication of a Raceform Index - 'the horses, their breeding, dams' sires and racing records', an idea proposed but not completed by Cheny 230 years earlier.

In spite of the reservations expressed above, there are many ways in which the Racing Calendar can be mined for information about the social and economic history of horseracing. What follows is based solely on the flat racing Calendars (Weatherbys also became responsible for publishing details of National Hunt rules and fixtures) from which two areas have been selected for closer examination. The first concerns the origins of female participation in the sport, the second looks at international aspects of racing.

\section{Always a woman?}

It has always been asserted that women were not allowed to take part in racing. [24] Yet there is no rule published in the Racing Calendar to that effect; if women were 'banned' from racing horses this was an unwritten law or social convention not a Jockey Club requirement. It was not uncommon in the second half of the nineteenth century for owners to race under a pseudonym and the usual story in circulation is that those women who were interested in the sport bought, owned and ran horses under male names. The examples most frequently cited are the formidable Duchess of Montrose, an acknowledged expert on thoroughbred racehorses who raced under the name ' $\mathrm{Mr}$ Manton' in the 1880s, and the actress Lillie Langtry, who was known as 'Mr Jersey' in the 1890s. These two 'gentlemen' can certainly be found in the lists of registered owners' colours printed annually in the Racing Calendar, Mr Manton's jockeys wearing scarlet and Mr Jersey's decked out in turquoise and fawn hoops. Their real identities were an open secret and it seems strange that they felt it necessary to 'disguise' themselves in this manner, particularly when other women were boldly registering silks under their own names and had been doing so for decades. 
A careful scrutiny of both Weatherbys' Calendar and Ruffs Guide to the Turf, another annual racing publication, shows that one or two female names crop up in the lists of colours from the late 1850s. In 1855 a Mr Osbaldeston raced in green with a red cap; by 1858 this combination has been assigned to Mrs Osbaldeston, her husband having presumably died, and she features for a number of years thereafter. In $1868 \mathrm{Mr} \mathrm{C}$. Snewing, owner of 1862 Derby winner, Caractacus, registered his colours as light blue with a white cap but Mrs W. Snewing preferred a gold jacket and green velvet cap with a gold tassel. From the late 1880s onwards, lady owners appear more often and more regularly: there are 8 in 1889, 14 in 1902 and 33 in 1910. Even Lillie Langtry had finally relinquished her pseudonym by 1907 .

It might be suggested that marital status or social rank were factors inhibiting open disclosure of horse ownership. Yet single women such as Miss Isabella Graham (1887) and Miss J Nicholl (1888), and others with titles - Lady Anne Blunt (1884), Lady Meux (1892) - rejected secrecy. Some husbands may have preferred their wives to race incognito but there are several examples of both spouses registering colours: Mr and Mrs T. Chaloner for over thirty years from the 1890s (she had two sets of racing silks), $\mathrm{Mr}$ and Mrs J. Shepherd and Mr and Mrs J Collins (both from 1902). It may be that some names using the style 'Mrs' were, in fact, not their own - something that cannot now be ascertained. It is scarcely conceivable that any man would have taken a female pseudonym if he wished to remain anonymous: there were so few female titles in this period that they stood out sharply amongst the Lords, Sirs and Misters. The most likely explanation is that some women felt bound to observe a supposed convention for family or societal reasons but that a small group of female owners in the late Victorian and Edwardian years were willing to flout this practice. The growth in numbers coincides with the gathering momentum of the women's suffrage movement, many supporters of which joined ladies' clubs, formed in imitation of male establishments, were actively engaged in sporting activities, and took an increasing interest in what had previously been seen as masculine preserves. [25] After World War I - and the partial granting of the vote for women - the number of female owners grew more rapidly; 160 were registered in $1921,8 \%$ of the total, 467 in 1936 (18\%). By 1958 nearly $30 \%$ of owners registering colours were women.

The Racing Calendar also provides information about women in other branches of horseracing, as subscribers to the volume (names were listed until 1888) and as thoroughbred breeders, firstly under the annual 'List of foals', later in the reports of bloodstock sales. Initially most of the women named in subscription lists were associated with inns and hotels - Mrs Howard of the Coach and Horses, Dover Street, London is mentioned in 1846, along with Mrs W Smith of the Albion Hotel, Liverpool and five others. By the 1880s a few notables such as the Duchess of Montrose, Lady C Ker, the Honourable Mrs Ramsay and the Honourable Mrs H Pigott-Carleton are listed but they remain a tiny group. Breeders had also been represented from the 1840 s, seldom more than six each year until the 1880 s, but thereafter their numbers increased in a similar fashion to lady owners: 22 (including five members of the aristocracy) in 1888, 39 in 1910,83 in 1921. Women may not have played a significant part in the nineteenth and 
early twentieth-century business of horseracing but they were not completely excluded, as generally believed.

\section{Far, far away}

The Racing Calendar is not a purely British affair; the list of subscribers demonstrates an overseas interest in the English turf from the late eighteenth century. Nine subscriptions in 1804, mostly from North America, had become 56 by 1839, 82 by 1865 and 125 - over $10 \%$ of the total - by 1888 . Most copies found their way to France, Germany and America but a few were destined for Australia, New Zealand, South Africa and the East Indies. Some were purchased by overseas racing organisations and turf authorities - the Bombay Turf Club, the Moscow Racing Society and the Jockey Clubs of Argentina and the United States. Others became the property of Russian princes, Hungarian counts and Prussian barons. From the 1860s onwards, however, between onethird and one-half went to France, reflecting not only French interest - and considerable success - in English racing but the fact that there was a sizeable community of Englishmen training horses across the Channel, particularly at the Newmarket of French racing, Chantilly. Here generations of Pratts and Carters trained for local owners and introduced their English customs - le five o'clock tea, le Harvest Festival and le Cricket $\mathrm{Club}$ - to the local community. [26] Six individual Pratts subscribed to the Racing Calendar in 1880.

Overseas racing featured briefly in Heber's and the earliest Weatherbys' Calendars, but it was 1864 before European meetings, mostly in France, were regularly reported. The number of French meetings covered in the later nineteenth century seems surprising, not just the important fixtures at Chantilly and Paris but racing at provincial courses the length and breadth of the country, from Pau and Avignon in the south to Brest in the north-west and Nancy in the north-east. In 1868, 54 places in France are mentioned in the Racing Calendar together with 6 in Belgium. This is perhaps less strange when the jockeys are considered - the majority appear to be English. Browns, Hunters, Pratts, Whittakers, Giffords, Flatmans, Smiths, Greens, Thomsons and Barlows are only a few of the Anglo-Saxon names to appear and it seems probably that, like the trainers mentioned above, they were based in France. For the most prestigious races such as the Grand Prix de Paris they were sometimes joined by top English jockeys. George Fordham, winner of 16 English Classics, won the Prix du Jockey-Club - the French Derby - in 1868; he was able to do so without jeopardising his English rides because the major French races took place on Sundays, a rest day at home. Nevertheless, in an era of steam train, boat and horse-drawn carriage, a trip to Chantilly or Paris for the day was not to be undertaken lightly.

By the beginning of the twentieth century, reports of 'Continental racing' in the Calendar had become increasingly selective. Only twenty-five 'places of sport' were listed in 1902. The small French country courses had gone the way of their English counterparts, leaving 18 of the more significant venues - Saint Cloud, Maisons Laffitte, Deauville, Chantilly - and several of the larger tracks around Europe (Baden Baden, Cologne, Vienna and Turin). British jockeys were still in evidence but they had now been 
joined by a number of Americans including Johnny Reiff and Danny Maher. Both were licensed to ride in Britain - Maher was third in the jockeys' championship in 1902 - but Reiff seems to have spent a large part of the year in France where he won the Prix du Jockey-Club and the French Two Thousand Guineas, and was third in the French Oaks. [27]

'Continental racing' ceased in 1914. French races re-appeared in 1938 for two seasons, and recommenced in 1945 but the reports were scanty, normally featuring only the French classics and a few other major races at Longchamp, such as the Prix de l'Arc de Triomphe. English jockeys earning a living in France had virtually disappeared, although a couple of Australians - 'Scobie' Breasley and 'Rae' Johnstone - were successful in major French races in the post-war period. In a complete reversal of fortune, French jockeys regularly obtained temporary licences to ride in Britain; the 1950s saw up to a dozen plying their trade at the major racecourses in the south of England and meeting with considerable success. Roger Poincelet won the Two Thousand Guineas in 1952, the One Thousand Guineas and Oaks in 1960, the Derby in 1961 and the King George VI and Queen Elizabeth Diamond Stakes twice, in 1955 and 1961. French owner/trainer partnerships also won the Derby in 1950, 1955, 1956, 1963 and 1965, and the Oaks in 1947, 1950, 1956, 1958 and 1962 while British raids across to France appear to have ceased. By the mid-1960s reports of European races were no longer included in the Racing Calendar.

\section{A simple twist of fate?}

The Racing Calendar will never receive widespread recognition as a sporting text because it is fated to reflect a relatively minority sport in twenty-first century terms. The British Horseracing Authority may paint a rosy picture -5.86 million people went racing in 2006; the industry had an overall economic impact of $£ 2.86$ billion in 2004/05; racing is second only to football measured by revenue and spectator numbers (including television viewers) - but most racegoers are simply interested in a day out with food, drink and an opportunity to gamble. [28] Very few have any knowledge of the sport's lengthy history; few sports historians have any interest at all in either horseracing or equestrian events in general.

One reason for this may be that horses are no longer part of everyday life as they were in Victorian and Edwardian times. Another is that racing does not have a genuine 'fan base' - spectators are not there to follow a team or a star athlete, or share in the communal experience of winning or losing. There are no amateur racing historians or statisticians out there, no fanzines. Nor, unlike most sports, can horseracing encourage participation - there is no 'grass roots' and most fans of racing will never even have ridden a horse, let alone raced one. There are also those who think that racing is a form of cruelty to animals and should be next in line for a ban, following the suppression of foxhunting. Who, outwith the narrow confines of the industry and the daytrippers, actually cares about horseracing? 
The Racing Calendar is a remarkable record of one of our oldest national sports. There is scope within its pages for revealing much more, especially about twentiethcentury racing which has so far been under-researched. The texts are there, the evidence is waiting to be unearthed but unless another Wray Vamplew comes to the fore hundreds of volumes of the Racing Calendar will simply gather dust in library vaults.

\section{Notes}

[1] Wray Vamplew, The Turf: a social and economic history of horse racing (London, 1976).

[2] Wray Vamplew, 'Still crazy after all those years: Continuity in a changing labour market for professional jockeys', Contemporary British History, 14 (2) (2000), p.140, n.2.

[3] Mike Huggins, Flat racing and British society 1750-1914 (London, 2000), p.xi.

[4] Tim Fitzgeorge-Parker, The Spoilsports (London, 1968), p.18.

[5] C.M. Prior, The history of the Racing Calendar and Stud Book (London, 1926), p.94, pp.108-09.

[6] Ibid., p.147.

[7] Vamplew, The Turf, p.33.

[8] Huggins, Flat racing, p.65, n.85. A change in the rules from 1936 removed the entitlement to colours for life. Thereafter owners had to register their colours annually. [9] Douglas Booth, The field; Truth and fiction in sport history (London, 2005), p.85. Briefly, Booth reminds historians that official documents should not be viewed as neutral sites of information but as 'managed' sources, open to manipulation and concealment, dependent on purpose, personnel and policy for their retention.

[10] Prior, History, p.95.

[11] Norman Barrett, The Daily Telegraph chronicle of horse racing (Enfield, 1995), p.9; Barry Campbell, Horse racing in Britain (London, 1977), p.202; Roger Mortimer, The encyclopaedia of flat racing (London, 1971), p.389; Wray Vamplew, 'Reduced horse power: the Jockey Club and the regulation of British horseracing', Entertainment Law, 2 (3) (2003), p.109 n.16.

[12] Prior, History, pp.151-158.

[13] Huggins, Flat racing, p.174; Vamplew, 'Reduced horse power', p.100.

[14] Huggins, Flat racing, p.175.

[15] Booth, The field, pp.84-86. The Racing Calendar is an interesting historical record: is it an 'official' publication or a 'document of mass communication' in Booth's terms? (It is classified as a 'journal' in the catalogue of the copyright National Library of Scotland)

[16] John Fairfax-Blakeborough, The Analysis of the Turf (London, 1927), p.162.

[17] Huggins, Flat racing, p.20; Wray Vamplew and Joyce Kay, Encyclopedia of

British Horseracing (Abingdon, 2005), p.44.

[18] Quoted in Prior, History, p. 95.

[19] John Tyrrel, Running racing: the Jockey Club years since 1750 (London, 1997),

p.9.

[20] Prior, History, p.107.

[21] Tyrrel, Running racing, p.29. 
[22] For an explanation of nineteenth-century betting practices and the Jockey Club attitude to bets and bettors, see Huggins, Flat racing, pp.185-191.

[23] Tyrrel, Running racing, p.60.

[24] For example, Caroline Ramsden, Ladies in Racing (London, 1973), pp. 21-22;

Gillian Newsum, Women and Horses (London, 1988), pp.111-112; Huggins, Flat racing, p.45.

[25] For ladies' clubs, see Joyce Kay, 'No time for recreations till the vote is won? Suffrage activists and leisure in Edwardian Britain', Women's History Review, 16 (4) (2007), pp.15-23; for sporting activities, see Joyce Kay, 'It wasn't just Emily Davison! Sport, suffrage and society in Edwardian Britain', International Journal of the History of Sport, 25 (10) (2008), pp.9-13.

[26] Jean-Pierre Blay, 'Industrie hippique, immigration anglaise et structures sociales à Chantilly au XIX siècle', Revue Européenne des Migrations Internationales, 8 (2)

(1992), pp. 123-4, p.127.

[27] For a detailed examination of the 'American invasion', see Wray Vamplew, 'The American invasion of the English turf: a study in sporting technological transfer' in J.

Toleneer and R. Renson, eds., Old Borders, New Borders, No Borders (Leuven, 2000). [28] British Horseracing Authority website, http://www.britishhorseracing.com/inside_horseracing/media/2.5.7.1.asp?item=001579 Accessed 21 April 2009. 